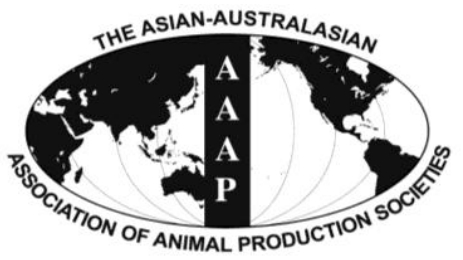

Asian Australas. J. Anim. Sci.

Vol. 26, No. 11 : 1614-1621 November 2013

http://dx.doi.org/10.5713/ajas.2012.12698

Www.ajas.info

pISSN 1011-2367 elSSN 1976-5517

\title{
Effects of Graded Levels of Montmorillonite on Performance, Hematological Parameters and Bone Mineralization in Weaned Pigs
}

\author{
Q. W. Duan, J. T. Li, L. M. Gong, H. Wu, and L. Y. Zhang* \\ State Key Laboratory of Animal Nutrition, Ministry of Agriculture Feed Industry Centre, \\ China Agricultural University, Beijing 100193, China
}

\begin{abstract}
The aim of this study was to investigate the effects of graded levels of montmorillonite, a constituent of clay, on performance, hematological parameters and bone mineralization in weaned pigs. One hundred and twenty, 35-d-old crossbred pigs (Duroc $\times$ Large White $\times$ Landrace, $10.50 \pm 1.20 \mathrm{~kg}$ ) were used in a $28-\mathrm{d}$ experiment and fed either an unsupplemented corn-soybean meal basal diet or similar diets supplemented with $0.5,1.0,2.5$ or $5.0 \%$ montmorillonite added at the expense of wheat bran. Each treatment was replicated six times with four pigs (two barrows and two gilts) per replicate. Feed intake declined (linear and quadratic effect, $\mathrm{p}<$ 0.01 ) with increasing level of montmorillonite while feed conversion was improved (linear and quadratic effect, $\mathrm{p}<0.01$ ). Daily gain was unaffected by dietary treatment. Plasma myeloperoxidase declined linearly $(\mathrm{p}=0.03)$ with increasing dietary level of montmorillonite. Plasma malondialdehyde and nitric oxide levels were quadratically affected $(p<0.01)$ by montmorillonite with increases observed for pigs fed the 0.5 and $1.0 \%$ levels which then declined for pigs fed the 2.5 and $5.0 \%$ treatments. In bone, the content of potassium, sodium, copper, iron, manganese and magnesium were decreased (linear and quadratic effect, $\mathrm{p}<0.01$ ) in response to an increase of dietary montmorillonite. These results suggest that dietary inclusion of montmorillonite at levels as high as $5.0 \%$ does not result in overt toxicity but could induce potential oxidative damage and reduce bone mineralization in pigs. (Key Words: Montmorillonite, Growth Performance, Hematological Parameters, Bone Mineralization, Weaned Pig)
\end{abstract}

\section{INTRODUCTION}

Montmorillonite, one of the main constituents of clays, is formed by a 2:1 condensation of layers with octahedrally coordinated aluminum sandwiched between two layers of tetrahedrally coordinated silica (Ramos and Hernandez, 1996). Montmorillonite can adsorb organic materials either on its surface or within its inter-laminar spaces by an exchange of cations present in these spaces (Phillip et al., 1993). Due to these physical-chemical properties, montmorillonite has been intensively used in animal diets to promote production, reduce the detrimental effects induced by mycotoxin-contaminated feeds and protect against enteric diseases in swine (Papaioannou et al., 2004; Bailey et al., 2006).

Although clay-based adsorbents are generally considered to be safe animal feed additives, it has been suggested that before using additives in animal feed, clear evidence of their purity and their negligible nutrient

\footnotetext{
* Corresponding Author: L. Y. Zhang. Tel: +86-10-6273-1272, Fax: +86-10-6273-3700, E-mail: zhangliying01@ sina.com Submitted Dec. 17, 2012; Accepted Apr. 3, 2013; Revised Jun. 3, 2013
}

interactions must be evaluated both in vitro and in vivo (Miles and Henry, 2007; Phillip et al., 2009). The European Food Safety Authority also places importance on testing mycotoxin-detoxifying agents for safety (Anonymous, 2010).

Some short-term animal studies have reported no observable adverse effects following the addition of montmorillonite clay to the diet at concentrations as high as $2.0 \%$ (Wiles et al., 2004). However, safety evaluation studies in pigs are limited. Whether this effective and lowcost strategy will pose any hidden risk in response to the increasing inclusion dosage in pig diets needs further research. Therefore the objective of the current experiment was to determine the effect of dietary supplementation of montmorillonite on performance, relative organ weight, hematological and serum biochemistry parameters as well as anti-oxidative status, and bone mineralization at higher than recommended levels $(0.5 \%$, manufacturer instruction) in weaned pigs.

\section{MATERIALS AND METHODS}

The Animal Welfare Committee of China Agricultural Copyright (@) 2013 by Asian-Australasian Journal of Animal Sciences 
University (Beijing, China) approved the animal care protocol used for this experiment. The montmorillonite used in this study was purchased from the Zhejiang Sanding Technology Company (Zhejiang, China). The content of montmorillonite in the clay exceeded 95\% (manufacturer's specifications).

\section{Diets and experimental design}

One hundred and twenty 35-d-old crossbred weaned pigs (Duroc $\times$ Large White $\times$ Landrace) weighing $10.5 \pm 1.2 \mathrm{~kg}$ were blocked by weight, sex and ancestry and allotted to one of five dietary treatments in a $28-\mathrm{d}$ experiment. The dietary treatments consisted of an unsupplemented cornsoybean meal basal diet or similar diets supplemented with $0.5,1.0,2.5$, or $5.0 \%$ montmorillonite added at the expense of wheat bran. The diets were formulated to meet or exceed requirements suggested by the National Research Council (1998) for 10 to $20 \mathrm{~kg}$ pigs (Table 1).

All pigs were housed indoors in $1.2 \times 2.0 \mathrm{~m}$ concretefloored pens with half of the pen area solid concrete and the remainder plastic slats. The pigs were provided ad libitum access to feed and water throughout the experimental period. The room temperature was maintained at 25 to $27^{\circ} \mathrm{C}$. Each treatment was replicated six times with four pigs (two barrows and two gilts) per pen.
The pigs were weighed individually on $\mathrm{d} 0$ and 28 of the experiment and feed consumption was measured per pen at same time. These values were used to calculate weight gain, feed intake and feed conversion. At the end of the experiment, one pig was randomly chosen from each pen and blood samples were collected from the jugular vein using EDTA- $\mathrm{K}_{2}$ tubes and tubes without anticoagulant, respectively. Serum and plasma samples were separated by centrifugation at $1,342 \times g$ at $4^{\circ} \mathrm{C}$ for $10 \mathrm{~min}$, and stored at $-20^{\circ} \mathrm{C}$ until further analyzed.

After blood sampling on d 28, the same pigs were chosen for slaughter. The pigs were stunned by electric shock and then killed by exsanguination. The heart, liver, spleen, lung and kidney were collected and weighed to calculate the relative organ weight, measured as the ratio of the wet organ weight to final body weight $(\mathrm{g} / \mathrm{kg})$. The third and fourth metatarsal bones were removed from the right hind-legs and dissected free of soft tissues (Eklou et al., 1999). The metatarsal bones were weighed and then stored in a refrigerator $\left(4^{\circ} \mathrm{C}\right)$ for less than $48 \mathrm{~h}$ before being tested for bone breaking strength.

\section{Chemical analysis}

Diets were analyzed according to the methods of the Association of Official Analytical Chemists (2000) for

Table 1. Ingredient composition and nutrient content of experimental diets (\% as-fed basis)

\begin{tabular}{|c|c|c|c|c|c|}
\hline \multirow{2}{*}{ Items } & \multicolumn{5}{|c|}{ Level of montmorillonite (\%) } \\
\hline & 0.0 & 0.5 & 1.0 & 2.5 & 5.0 \\
\hline \multicolumn{6}{|l|}{ Ingredient (\%) } \\
\hline Corn & 52.00 & 52.00 & 52.00 & 52.00 & 52.00 \\
\hline Soybean meal & 21.00 & 21.00 & 21.00 & 21.00 & 21.00 \\
\hline Fish meal & 5.00 & 5.00 & 5.00 & 5.00 & 5.00 \\
\hline Soybean protein concentrate & 5.00 & 5.00 & 5.00 & 5.00 & 5.00 \\
\hline Whey & 6.00 & 6.00 & 6.00 & 6.00 & 6.00 \\
\hline Wheat bran & 5.00 & 4.50 & 4.00 & 2.50 & 0.00 \\
\hline Soybean oil & 3.00 & 3.00 & 3.00 & 3.00 & 3.00 \\
\hline Dicalcium phosphate & 0.90 & 0.90 & 0.90 & 0.90 & 0.90 \\
\hline Limestone & 0.60 & 0.60 & 0.60 & 0.60 & 0.60 \\
\hline DL-methionine (98\%) & 0.25 & 0.25 & 0.25 & 0.25 & 0.25 \\
\hline L-lysine $\cdot \mathrm{HCl}(98 \%)$ & 0.15 & 0.15 & 0.15 & 0.15 & 0.15 \\
\hline Sodium chloride & 0.10 & 0.10 & 0.10 & 0.10 & 0.10 \\
\hline Vitamin-mineral premix ${ }^{1}$ & 1.00 & 1.00 & 1.00 & 1.00 & 1.00 \\
\hline Montmorillonite & 0.00 & 0.50 & 1.00 & 2.50 & 5.00 \\
\hline \multicolumn{6}{|l|}{ Nutrient content $(\%)^{2}$} \\
\hline Metabolizable energy (MJ/kg) & 13.51 & 13.46 & 13.42 & 13.29 & 13.46 \\
\hline Crude protein & 21.03 & 20.92 & 20.65 & 20.44 & 20.27 \\
\hline Calcium & 0.84 & 0.79 & 0.80 & 0.87 & 0.90 \\
\hline Total phosphorus & 0.69 & 0.70 & 0.72 & 0.71 & 0.75 \\
\hline Methionine & 0.59 & 0.57 & 0.54 & 0.55 & 0.53 \\
\hline Lysine & 1.30 & 1.28 & 1.25 & 1.27 & 1.25 \\
\hline
\end{tabular}

${ }^{1}$ Provided per kilogram diet: vitamin A, 9,000 IU; vitamin $\mathrm{D}_{3}, 3,000 \mathrm{IU}$; vitamin $\mathrm{E}, 20 \mathrm{IU}$; vitamin $\mathrm{K}_{3}, 3.0 \mathrm{mg}$; thiamine, $1.5 \mathrm{mg}$; riboflavin, $4.0 \mathrm{mg}$; pyridoxine, $3.0 \mathrm{mg}$; cobalamin, $0.2 \mathrm{mg}$; biotin, $0.1 \mathrm{mg}$; pantothenic acid, $30 \mathrm{mg}$; nicotinic acid, $15 \mathrm{mg}$; iron, $75 \mathrm{mg}$; copper, $150 \mathrm{mg}$; zinc, $75 \mathrm{mg}$; manganese, $60 \mathrm{mg}$; iodine, $0.35 \mathrm{mg}$; selenium, $0.3 \mathrm{mg}$.

${ }^{2}$ All nutrient levels except metabolizable energy were analyzed and values are the means of two determinations. 
Table 2. Performance of weaned pigs fed diets containing graded levels of montmorillonite (d 0 to 28$)^{1}$

\begin{tabular}{|c|c|c|c|c|c|c|c|c|c|}
\hline \multirow{2}{*}{ Items } & \multicolumn{5}{|c|}{ Level of montmorillonite (\%) } & \multirow{2}{*}{ SEM } & \multicolumn{3}{|c|}{$\mathrm{p}$ value } \\
\hline & 0.0 & 0.5 & 1.0 & 2.5 & 5.0 & & ANOVA & Linear & Quadratic \\
\hline Weight gain $(\mathrm{kg} / \mathrm{d})$ & 0.48 & 0.41 & 0.43 & 0.44 & 0.45 & 0.07 & 0.65 & 0.72 & 0.44 \\
\hline Feed intake (kg/d) & 0.83 & 0.74 & 0.76 & 0.70 & 0.67 & 0.09 & 0.05 & $<0.01$ & 0.01 \\
\hline Feed conversion & 1.74 & 1.83 & 1.78 & 1.61 & 1.50 & 0.15 & $<0.01$ & $<0.01$ & $<0.01$ \\
\hline
\end{tabular}

${ }^{1}$ Values are the means of six replicates of four pigs.

calcium (AOAC method 927.02), and total phosphorus (AOAC method 995.11). Crude protein was determined by the method of Thiex et al. (2002). For dietary lysine and methionine determination, samples were acid hydrolyzed either with or without preoxidation with performic acid (AOAC method 944.12), respectively, and the amino acids were chromatographically separated and quantified using a Model L-8900 Amino Acid Analyzer (Hitachi, Tokyo, Japan).

Serum samples were analyzed for alanine aminotransferase, aspartate aminotransferase, alkaline phosphatase, total protein, albumin, urea nitrogen, creatinine, glucose and total bilirubin using kits purchased from the Biosino Biotechnology and Science Company (Beijing, China) following the standard procedures described by the manufacturer. Analyses were conducted on a Hitachi Auto-Analyzer (Hitachi 7020, Tokyo, Japan). Plasma samples were analyzed for myeloperoxidase, superoxide dismutase, malondialdehyde and nitric oxide levels using kits purchased from the Jiancheng Institute of Biological Engineering (Nanjing, China).

The bone breaking strength, a trait for assessing the bone mineralization in swine as described by Crenshaw et al. (1981), was tested on a universal testing machine (Reger 3010, Shenzhen, China). After that, bones were ashed following the procedure described by Ward et al. (1991) for determination of their mineral element.

The mineral content in both the serum and bones, including calcium, potassium, sodium, zinc, copper, iron, manganese and magnesium, were determined using an inductively coupled plasma-mass spectrometer (Agilent
7500 series, Santa Clara, CA, USA). Serum and bone inorganic phosphorus concentration was determined by modifications of the method of Fiske and Subbarow (1925).

\section{Statistical analysis}

Analysis of variance was performed using replicate means. Differences between treatments were examined using a one-way ANOVA (SAS Institute, 1996). The linear and quadratic effects of montmorillonite level were assessed using orthogonal polynomials. A p-value of less than 0.05 was considered statistically significant.

\section{RESULTS}

\section{Performance}

The effects of different levels of montmorillonite on growth performance in weaned pigs are presented in Table 2. Weight gain was unaffected by dietary treatment $(\mathrm{p}>0.05)$. Feed intake declined (linear and quadratic, $\mathrm{p}<0.01$ ) with increasing dietary level of montmorillonite. As a result, feed conversion was significantly improved as the dietary level of montmorillonite increased.

\section{Serum biochemistry}

Table 3 shows the effect of montmorillonite on the serum biochemistry of pigs. No significant difference was found in the hematologic parameters of pigs supplemented with different levels of montmorillonite. The values of for biochemical parameters measured in the serum of pigs were within the range of common references (Kaneko et al., 1997), which indicated that 0.0 to $5.0 \%$ montmorillonite

Table 3. Serum biochemical measures of weaned pigs fed diets containing graded levels of montmorillonite $(\mathrm{d} 28)^{1}$

\begin{tabular}{|c|c|c|c|c|c|c|c|c|c|}
\hline & \multicolumn{5}{|c|}{ Level of montmorillonite (\%) } & \multirow{2}{*}{ SEM } & \multicolumn{3}{|c|}{$\mathrm{p}$ value } \\
\hline & 0.0 & 0.5 & 1.0 & 2.5 & 5.0 & & ANOVA & Linear & $\overline{\text { Quadratic }}$ \\
\hline Alanine aminotransferase (U/L) & 11.82 & 11.15 & 11.38 & 11.05 & 10.42 & 2.29 & 0.88 & 0.31 & 0.60 \\
\hline Aspartate aminotransferase (U/L) & 40.55 & 37.80 & 42.77 & 41.48 & 43.91 & 7.77 & 0.71 & 0.29 & 0.55 \\
\hline Alkaline phosphatase (U/L) & 176.01 & 172.29 & 187.53 & 208.58 & 199.40 & 28.25 & 0.17 & 0.79 & 0.83 \\
\hline Total protein $(\mathrm{g} / \mathrm{L})$ & 51.93 & 51.03 & 51.06 & 53.48 & 50.42 & 4.09 & 0.73 & 0.91 & 0.95 \\
\hline Albumin (g/L) & 38.04 & 38.61 & 39.62 & 38.52 & 38.57 & 1.19 & 0.26 & 0.55 & 0.20 \\
\hline Urea nitrogen $(\mathrm{mmol} / \mathrm{L})$ & 3.82 & 4.28 & 4.11 & 4.01 & 3.86 & 0.40 & 0.29 & 0.72 & 0.18 \\
\hline Creatinine $(\mu \mathrm{mol} / \mathrm{L})$ & 48.27 & 49.37 & 46.39 & 48.96 & 50.29 & 3.26 & 0.33 & 0.40 & 0.35 \\
\hline Glucose (mmol/L) & 4.46 & 4.43 & 4.32 & 4.30 & 4.61 & 0.64 & 0.92 & 0.82 & 0.70 \\
\hline Total bilirubin $(\mu \mathrm{mol} / \mathrm{L})$ & 7.82 & 7.68 & 8.01 & 7.94 & 7.78 & 0.54 & 0.85 & 0.15 & 0.09 \\
\hline
\end{tabular}

\footnotetext{
${ }^{1}$ Values are the means of six replicates.
} 
Table 4. Plasma indicators of oxidative stress in weaned pigs fed diets containing graded levels of montmorillonite $(\mathrm{d} 28)^{1}$

\begin{tabular}{|c|c|c|c|c|c|c|c|c|c|}
\hline & \multicolumn{5}{|c|}{ Level of montmorillonite (\%) } & \multirow{2}{*}{ SEM } & \multicolumn{3}{|c|}{$\mathrm{p}$ value } \\
\hline & 0.0 & 0.5 & 1.0 & 2.5 & 5.0 & & ANOVA & Linear & Quadratic \\
\hline Myeloperoxidase (U/L) & 46.33 & 49.02 & 44.24 & 42.75 & 43.83 & 4.92 & 0.22 & 0.03 & 0.09 \\
\hline Superoxide dismutase $(\mathrm{U} / \mathrm{mL})$ & 67.38 & 71.16 & 70.73 & 65.93 & 64.02 & 6.16 & 0.23 & 0.42 & 0.28 \\
\hline Malondialdehyde (nmol/mL) & 7.92 & 8.95 & 8.55 & 7.85 & 7.89 & 1.07 & 0.30 & $<0.01$ & $<0.01$ \\
\hline Nitric oxide $(\mu \mathrm{mol} / \mathrm{L})$ & 36.58 & 48.71 & 48.67 & 34.04 & 21.01 & 5.23 & $<0.01$ & 0.09 & 0.24 \\
\hline
\end{tabular}

${ }^{1}$ Values are the means of six replicates.

Table 5. Serum mineral element concentrations of weaned pigs fed diets containing graded levels of montmorillonite (d 28) ${ }^{1}$

\begin{tabular}{|c|c|c|c|c|c|c|c|c|c|}
\hline \multirow{2}{*}{ Items } & \multicolumn{5}{|c|}{ Level of montmorillonite (\%) } & \multirow{2}{*}{ SEM } & \multicolumn{3}{|c|}{$\mathrm{p}$ value } \\
\hline & 0.0 & 0.5 & 1.0 & 2.5 & 5.0 & & ANOVA & Linear & Quadratic \\
\hline Calcium $(\mu \mathrm{g} / \mathrm{mL})$ & 85.0 & 86.0 & 90.3 & 94.3 & 89.0 & 6.94 & 0.52 & 0.20 & 0.30 \\
\hline Phosphorus (mmol/L) & 2.24 & 2.17 & 2.15 & 2.24 & 1.92 & 0.39 & 0.63 & 0.27 & 0.44 \\
\hline Potassium ( $\mu \mathrm{g} / \mathrm{mL})$ & 176 & 199 & 196 & 196 & 187 & 16.7 & 0.48 & 0.50 & 0.20 \\
\hline Sodium $(\mu \mathrm{g} / \mathrm{mL})$ & 2,606 & 2,619 & 2,693 & 2,787 & 2,774 & 116.2 & 0.25 & 0.02 & 0.08 \\
\hline Zinc $(\mu \mathrm{g} / \mathrm{mL})$ & 0.75 & 0.74 & 0.70 & 0.78 & 0.81 & 0.09 & 0.71 & 0.37 & 0.39 \\
\hline Copper $(\mu \mathrm{g} / \mathrm{mL})$ & 1.51 & 1.59 & 1.81 & 1.56 & 1.73 & 0.17 & 0.23 & 0.25 & 0.41 \\
\hline Iron $(\mu \mathrm{g} / \mathrm{mL})$ & 1.57 & 1.58 & 1.71 & 1.66 & 1.47 & 0.40 & 0.96 & 0.85 & 0.75 \\
\hline Manganese $(\mu \mathrm{g} / \mathrm{mL})$ & $\mathrm{ND}^{2}$ & ND & ND & ND & ND & ND & ND & ND & ND \\
\hline Magnesium $(\mu \mathrm{g} / \mathrm{mL})$ & 18.67 & 18.67 & 19.67 & 22.67 & 19.67 & 1.98 & 0.16 & 0.15 & 0.26 \\
\hline
\end{tabular}

${ }^{1}$ Values are the means of six replicates. ${ }^{2}$ ND $=$ Not detected.

supplementation had no influence on serum biochemical indexes.

\section{Plasma specific indicators}

Myeloperoxidase levels declined with increasing level of montmorillonite (linear effect, $\mathrm{p}=0.03$ ) (Table 4). Malondialdehyde levels were quadratically affected $(\mathrm{p}<$ 0.01 ) by montmorillonite with increases observed for pigs fed the 0.5 and $1.0 \%$ levels which then declined for pigs fed the 2.5 and $5.0 \%$ treatments. Plasma nitric oxide levels increased with montmorillonite inclusion rates of $0.5 \%$ (48.71 $\mu \mathrm{mol} / \mathrm{L})$ and $1.0 \%(48.67 \mu \mathrm{mol} / \mathrm{L})$ in comparison to the control $(36.58 \mu \mathrm{mol} / \mathrm{L})$, and then decreased markedly $(\mathrm{p}<0.01)$ in the $2.5(34.04 \mu \mathrm{mol} / \mathrm{L})$ and $5.0 \%(21.01$ $\mu \mathrm{mol} / \mathrm{L})$ montmorillonite treatments. Superoxide dismutase levels were unaffected by treatment $(\mathrm{p}>0.05)$.

\section{Serum mineral content}

The effect of montmorillonite supplementation on serum mineral content is presented in Table 5. Serum minerals were unaffected by montmorillonite level ( $p>$ $0.05)$.

\section{Relative organ weights}

At necropsy, there were no obvious gross abnormalities in the major organs of interest (heart, liver, spleen, lung, and kidney) in pigs. The relative weights for these organs, calculated as the ratio of wet organ weight to final body weight $(\mathrm{g} / \mathrm{kg})$, were unaffected $(\mathrm{p}>0.05)$ by dietary treatment (Table 6).

\section{Bone mineralization}

The results of pig skeleton characteristics are shown in Table 7. Dietary montmorillonite supplementation had no influence on weight or breaking strength of the third and fourth metatarsal bones of pigs. However, it significantly affected bone mineral element content. The content of potassium, sodium, copper, iron, manganese and

Table 6. Relative organ weight of weaned pigs fed diets containing graded levels of montmorillonite $(\mathrm{d} 28)^{1,2}$

\begin{tabular}{|c|c|c|c|c|c|c|c|c|c|}
\hline \multirow{2}{*}{ Items $^{3}$} & \multicolumn{5}{|c|}{ Level of montmorillonite (\%) } & \multirow{2}{*}{ SEM } & \multicolumn{3}{|c|}{$\mathrm{p}$ value } \\
\hline & 0.0 & 0.5 & 1.0 & 2.5 & 5.0 & & ANOVA & Linear & Quadratic \\
\hline Heart $(\mathrm{g} / \mathrm{kg})$ & 5.02 & 4.55 & 4.64 & 5.11 & 5.08 & 0.54 & 0.24 & 0.35 & 0.21 \\
\hline Liver (g/kg) & 24.89 & 27.09 & 27.07 & 28.70 & 26.98 & 2.83 & 0.27 & 0.12 & 0.11 \\
\hline Spleen $(\mathrm{g} / \mathrm{kg})$ & 1.62 & 1.59 & 1.70 & 1.73 & 1.64 & 0.20 & 0.72 & 0.46 & 0.62 \\
\hline Lung $(g / k g)$ & 10.71 & 11.00 & 10.88 & 10.54 & 11.30 & 1.66 & 0.94 & 0.72 & 0.90 \\
\hline Kidney $(\mathrm{g} / \mathrm{kg})$ & 4.96 & 4.88 & 5.05 & 5.43 & 5.15 & 0.59 & 0.55 & 0.23 & 0.48 \\
\hline
\end{tabular}

${ }^{1}$ Values are the means of six replicates. ${ }^{2}$ The relative organ weight is expressed as the ratio of wet organ weight to final body weight. 
Table 7. Characteristics of metatarsal bones in weaned pigs fed diets containing graded levels of montmorillonite $(\mathrm{d} 28)^{1}$

\begin{tabular}{|c|c|c|c|c|c|c|c|c|c|}
\hline \multirow{2}{*}{ Items } & \multicolumn{5}{|c|}{ Level of montmorillonite (\%) } & \multirow{2}{*}{ SEM } & \multicolumn{3}{|c|}{$\mathrm{p}$ value } \\
\hline & 0.0 & 0.5 & 1.0 & 2.5 & 5.0 & & ANOVA & Linear & Quadratic \\
\hline Weight (g) & 22.3 & 22.4 & 22.0 & 20.9 & 21.2 & 2.57 & 0.81 & 0.26 & 0.53 \\
\hline Breaking strength (N) & 305.2 & 270.0 & 268.3 & 294.3 & 302.8 & 46.99 & 0.50 & 0.75 & 0.26 \\
\hline \multicolumn{10}{|c|}{ Mineral content ( $\%$ of ash) } \\
\hline Calcium (\%) & 18.82 & 18.45 & 18.75 & 18.90 & 19.26 & 1.48 & 0.91 & 0.47 & 0.64 \\
\hline Phosphorus (\%) & 8.49 & 8.37 & 8.37 & 8.48 & 8.43 & 0.68 & 0.99 & 0.99 & 0.97 \\
\hline Potassium (\%) & 0.27 & 0.21 & 0.19 & 0.18 & 0.12 & 0.04 & $<0.01$ & $<0.01$ & $<0.01$ \\
\hline Sodium $(\%)$ & 2.04 & 1.62 & 1.52 & 1.31 & 0.88 & 0.27 & $<0.01$ & $<0.01$ & $<0.01$ \\
\hline Magnesium (\%) & 1.32 & 1.17 & 1.09 & 0.96 & 0.64 & 0.15 & $<0.01$ & $<0.01$ & $<0.01$ \\
\hline Zinc (mg/g) & 0.60 & 0.57 & 0.47 & 0.43 & 0.34 & 0.06 & 0.02 & 0.03 & 0.10 \\
\hline Iron $(\mathrm{mg} / \mathrm{g})$ & 0.29 & 0.27 & 0.17 & 0.21 & 0.14 & 0.05 & $<0.01$ & $<0.01$ & $<0.01$ \\
\hline Copper (mg/kg) & 6.60 & 4.43 & 3.09 & 4.03 & 3.00 & 1.70 & $<0.01$ & $<0.01$ & $<0.01$ \\
\hline Manganese $(\mathrm{mg} / \mathrm{kg})$ & 11.09 & 8.78 & 7.91 & 6.34 & 4.75 & 1.65 & $<0.01$ & $<0.01$ & $<0.01$ \\
\hline
\end{tabular}

${ }^{1}$ Values are the means of six replicates.

magnesium linearly $(\mathrm{p}<0.01)$ and quadratically $(\mathrm{p}<0.01)$ decreased with an increase in montmorillonite addition. A linear effect of zinc content was also detected $(\mathrm{p}<0.05)$.

\section{DISCUSSION}

The strategy of including various binding agents or detoxifying clays in the diet has been given considerable attention in the scientific field. Generally, clays have been incorporated in animal diets as a nonnutritive additive to improve performance (Angulo et al., 1995). However, the results of previous experiments on the effect of clays on pig performance are inconsistent, showing either improvements (Pond et al., 1988; Papaioannou et al., 2004; Alexopoulos et al., 2007) or no effects (Shurson et al., 1984; Ward et al., 1991; Parisini et al., 1999). Different experiments with animals fed various clays in diets gave variable results on animal performance. Venglovsky et al. (1999) and Tauqir et al. (2001) reported that feed containing montmorillonite (1.0 to $2.0 \%$ ) could promote weight gain and feed efficiency of chickens and swine. The type of clays, producing area, supplemental content, and physical or chemical structural characteristics affected the feeding value of clays significantly (Hu et al., 2004). Nutritional level, environmental condition and animal species may also interfere with these effects (Prvulovic et al., 2012). In the present study, supplementation with montmorillonite had no effect on performance at low levels (0.5 and 1.0\%) compared with the control, which is in agreement with the research of Xia et al. (2005). Relatively high levels (2.5 and $5.0 \%$ ) of dietary montmorillonite addition to the diet markedly reduced feed intake. However, feed conversion was significantly increased. There is the possibility of dietary dilution affecting measured changes, since wheat bran was replaced by montmorillonite in the diet. However, the results in this study was not in accordance with the results obtained in previous studies, which demonstrated that dietary dilution could cause a compensatory increase in feed consumption to satisfy energy needs (Sibbald et al., 1960; Baker et al., 1968). It is possible that it is hard for pig to increase the feed intake to satisfy energy needs when diets containing a high level montmorillonite, which could cause palatability to be decreased. In this situation, the digestibility of nutrients in the diet increased accordingly.

Measures determined in blood, have generally been used to indicate the physiological status in response to altered conditions. In terms of serum biochemical analysis, the results of the present study confirmed no alterations. Moreover, all biochemical values in serum were within the reference range, a result similar to that obtained in previous studies. Vrzgula and Bartko (1984) found no effect of 5.0\% clinoptilolite supplementation on serum bilirubin concentration, aspartate aminotransferase and alanine aminotransferase activity in growing pigs. Alexopoulos et al. (2007) also concluded that supplementation of diets with clinoptilolite-rich tuff, at the inclusion rate of $2.0 \%$ on a long term basis, was not associated with any adverse effect on serum biochemical and hematological parameters evaluated in growing and fattening pigs. This suggests that dietary montmorillonite ingestion (levels up to 5.0\%) is unlikely to promote adverse effects on biochemical or physiological processes in pigs. Along with the homeostasis, no difference was found in relative organ weights, which further suggests no overt toxicity of dietary montmorillonite.

Reactive oxygen species, such as superoxide radical anion, singlet oxygen, hydrogen peroxide, and hydroxyl radical, are produced as by-products of oxidative metabolism, in which energy activation and electron reduction are involved (Kourie et al., 1998). The increase in intracellular levels of reactive oxygen species to such a level that cellular antioxidant defenses are insufficient to maintain these harmful molecules below a toxic threshold 
level is generally referred to as oxidative stress, which could play a role in the early stages of some pathophysiological processes (Prvulovic et al., 2012). The antioxidant enzymes, superoxide dismutase and myeloperoxidase, are known to serve as protective responses to eliminate reactive free radicals (Cheung et al., 2001). The present study suggests that values for myeloperoxidase in plasma declined linearly by dietary montmorillonite supplementation. This would indicate a decrease of resistance to oxidation. As a common monitor for lipid oxidation status, malondialdehyde concentration was quadratically affected by dietary montmorillonite supplementation. In recent years, nitric oxide was considered to be the cellular signal and functional molecule and may play a critical role in vivo in protecting mammalian cells from toxic reactive oxygen species (Wink et al., 1994). The results obtained from the current study have shown that, compared with the control, the plasma nitric oxide level increased with 0.5 and $1.0 \%$ montmorillonite incorporated in the diet. In contrast, it dramatically decreased when dietary montmorillonite was added up to 2.5 and $5.0 \%$. According to these findings, it is concluded that a relatively lower level $(0.5$ and $1.0 \%)$ of dietary montmorillonite supplementation could present a protective effect against oxidative damage induced by toxic reactive oxygen species, while an adverse effect emerged owing to the high level of montmorillonite incorporated up to $5.0 \%$ in the diet. Unfortunately, the specific mechanism through which this is achieved remains for further research.

Due to the non-specific adsorption property and ionexchange capacity of clays used in animal diets, their potential interaction with the dietary ingredients, such as minerals, has gradually attracted arising concern (Alexopoulos et al., 2007). Following this point, valuable conclusions have been drawn by comparative studies on different animal models. It has been reported that sodium and potassium concentrations in plasma or body tissues were not altered by the dietary use of clinoptilolite at the inclusion of 2.0 or $3.0 \%$ in growing lambs (Pond et al., 1984), growing pigs (Pond et al., 1989) and sows (Papaioannou et al., 2002), which is supported by the present study since no significant differences in serum concentration of sodium and potassium were found among the dietary treatments. Other studies have demonstrated a similar effect concerning serum calcium and phosphorous, together with other mineral element concentrations (including zinc, copper, iron, manganese, and magnesium), in growing pigs (Yannakopoulos et al., 2000), broilers (Dwyer et al., 1997) and dairy cows (Katsoulos et al., 2005). In agreement with these results, it was suggested that dietary montmorillonite supplementation causes no alteration of serum mineral concentrations in weaned pigs.

The effects of tissue mineral concentrations induced by dietary clay supplementation were reported by Pond et al. (1989) and Ward et al. (1991). Their studies demonstrated no effects on mineral accumulation in animal liver, kidney and bone, which is more or less inconsistent with the current study. Skeletal measures are usually used for assessing bone mineralization in both humans and pigs (Eklou et al., 1999). In the present experiment, supplementation with montmorillonite did not affect bone weight or breaking strength in pigs. However, bone mineral content decreased with an increase in dietary montmorillonite addition, except with regard to calcium and phosphorous. The possible explanation for this result is that montmorillonite has a large specific surface and effective adsorption, and due to the ion-exchange capacity, cations in the body were selectively adsorbed. This adsorption effect was significantly enhanced by the increase in montmorillonite addition level. Another possibility for the reduced mineral contents was due to diet nutrient dilution, since certain amount of wheat bran was replaced by montmorillonite supplementation. As calculated, pigs fed up to $5.0 \%$ montmorillonite ate $19.3 \%$ less than those of untreated, but bone mineral content was reduced by more than $50 \%$. Therefore, diet dilution could only partially cause the significant changes measured, but the main effect was more likely to attributed to the incorporated montmorillonite. Nevertheless, determining clear mechanisms for this effect remain for further research.

\section{IMPLICATIONS}

In conclusion, the findings of the current study suggest that the supplementation of diets with montmorillonite at an inclusion rate of 0.5 to $1.0 \%$ is not associated with any adverse effect on performance and health status in pigs. Montmorillonite addition to the diet at an inclusion level of 2.5 to $5.0 \%$ could reduce feed intake but improve feed utilization to some extent. Blood biochemical indices, serum mineral contents, and relative organ weights were not influenced by dietary montmorillonite incorporation. However, adding 5.0\% montmorillonite to the diet could induce oxidative damage and reduce bone mineralization in pigs. It is safe if used at recommended level of $0.5 \%$ montmorillonite, but appropriate supplemented nutrient of minerals is required along with the inclusion of montmorillonite in the diets. Further studies are necessary to clarify the possible mechanisms concerned in adsorption of nutrients via an in vitro experiment.

\section{ACKNOWLEDGEMENTS}

This study was supported by China Ministry of Agriculture (2012-Z12) and the National Key Basic Reseach Program of China (2012CB124702). The authors 
are grateful to the help in tissue sample collecting by Dr. E. Wayne Johnson and laboratory analysis by Kang Run.

\section{REFERENCES}

Alexopoulos, C., D. S. Papaioannou, P. Fortomaris, C. S. Kyriakis, G. A. Tserveni, A. Yannakopoulos, and S. C. Kyriakis. 2007. Experimental study on the effect of in-feed administration of a clinoptilolite-rich tuff on certain biochemical and hematological parameters of growing and fattening pigs. Livest. Sci. 111:230-241.

Angulo, E., J. Brufau, and G. E. Esteve. 1995. Effect of sepiolite on pellet durability in feeds differing in fat and fibre content. Anim. Feed Sci. Technol. 53:233-241.

Anonymous. 2010. Statement on the establishment of guidelines for the assessment of additives from the functional group 'substances for reduction of the contamination of feed by mycotoxins. EFSA J. 8:1693.

AOAC. 2000. Official methods of analysis. 17th edn. Association of Official Analytical Chemists, Gaithersburg, MD.

Bailey, C. A., G. W. Latimer, A. C. Barr, W. L. Wigle, A. U. Haq, J. E. Balthrop, and L. F. Kubena. 2006. Efficacy of montmorillonite clay (NovaSil PLUS) for protecting full-term broilers from aflatoxicosis. J. Appl. Poult. Res. 15:198-206.

Baker, D. H., D. E. Becker, A. H. Jensen, and B. G. Harmon. 1968. Effect of dietary dilution on performance of finishing swine. J. Anim. Sci. 27:1332-1335.

Cheung, C., G. J. Zheng, B. J. Richardson, and P. K. S. Lam. 2001 Relationship between tissue concentrations of polycyclic aromatic hydrocarbons and antioxidative responses of marine mussels. Aquat. Toxicol. 52:189-203.

Crenshaw, T. D., E. R. Peo, A. J. Lewis, and B. D. Moser. 1981. Bone strength as a trait for assessing mineralization in swine: A critical review of techniques involved. J. Anim. Sci. 53:827835.

Dwyer, M. R., L. F. Kubena, R. B. Harvey, K. Mayura, A. B. Sarr, S. Buckley, R. H. Bailey, and T. D. Phillips. 1997. Effect of inorganic adsorbents and cyclopiazonic acid in broiler chicken. Poult. Sci. 76:1141-1149.

Eklou, K. E., E. Zerath, C. Colin, C. Lacroix, X. Holy, I. Denis, and A. Pointillart. 1999. Calcium-regulating hormones, bone mineral content, breaking load and trabecular remodeling are altered in growing pigs fed calcium-deficient diets. J. Nutr. 129:188-193.

Fiske, C. H. and Y. S. Subbarow. 1925. The colorimetric determination of phosphorus. J. Biol. Chem. 66:375-400.

Hu, C. H., M. S. Xia, Z. R. Xu, and L. Xiong. 2004. Effects of copper-bearing montmorillonite on growth performance and digestive function of growing pigs. Asian-Aust. J. Anim. Sci. 17:1575-1581.

Kaneko, J. J., J. W. Harvey, and M. L. Bruss. 1997. Appendixes. In: Clinical Biochemistry of Domestic Animals, 5th Ed. (Ed. J. J. Kaneko, J. W. Harvey, and M. L. Bruss). Academic Press, San Diego. pp. 885-905.

Katsoulos, P. D., N. Roubies, N. Panousis, G. Arsenos, E. Christaki, and H. Karatzias. 2005. Effects of long-term dietary supplementation with clinoptilolite on incidence of parturient paresis and serum concentration of total calcium, phosphate, magnesium, potassium and sodium in dairy cows. Am. J. Vet.
Res. 66:2081-2085.

Kourie, J. I. 1998. Interaction of reactive oxygen species with ion transport mechanisms. Am. J. Physiol. Cell Physiol. 275:C1C24.

Miles, R. D. and P. R. Henry. 2007. Safety of improved Milbond$\mathrm{TX}^{\circledR}$ when fed in broiler diets at greater than recommended levels. Anim. Feed Sci. Technol. 138:309-317.

National Research Council. 1998. Nutrient requirements of swine. 10th Ed. National Academy Press, Washington, DC, USA.

Papaioannou, D. S., C. S. Kyriakis, A. Papasteriadis, N. Roumbies, A. Yannakopoulos, and C. Alexopoulos. 2002. Effect of infeed inclusion of a natural zeolite (clinoptilolite) on certain vitamin, macro and trace element concentrations in the blood, liver and kidney tissues of sows. Res. Vet. Sci. 72:61-68.

Papaioannou, D. S., C. S. Kyriakis, C. Alexopoulos, E. D. Tzika, Z S. Polizopoulou, and S. C. Kyriakis. 2004. A field study on the effect of the dietary use of a clinoptilolite-rich tuff, alone or in combination with certain antimicrobials, on the health status and performance of weaned, growing and finishing pigs. Res. Vet. Sci. 76:19-29.

Parisini, P., G. Martelli, L. Sardi, and F. Escribano. 1999. Protein and energy retention in pigs fed diets containing sepiolite. Anim. Feed Sci. Technol. 79:155-162.

Phillips, T. D., B. A. Clement, and D. L. Park. 1993. Approaches to reduction of aflatoxin in foods and feeds. In: The toxicology of aflatoxins: Human health, veterinary, and agricultural significance (Ed. D. L. Eaton and J. D. Groopman). Academic Press, London. pp. 383- 406.

Phillips, T. D., C. A. Marroquin, Y. Deng, J. F. Taylor, C. T. Hallmark, and N. M. Johnson. 2009. In vitro and in vivo characterization of mycotoxin-binding additives used for animal feeds in Mexico. Food Addit. Contam. A. 26:733-743.

Pond, W. G., J. T. Yen, and J. T. Crouse. 1989. Tissue mineral element content in swine fed clinoptilolite. Bull. Environ. Contam. Toxicol. 42:735-742.

Pond, W. G., J. T. Yen, and V. H. Varel. 1988. Response of growing swine to dietary copper and clinoptilolite supplementation. Nutr. Rep. Int. 37:797-803.

Pond, W. G., S. M. Laurent, and H. D. Orloff. 1984. Effect of dietary clinoptilolite or zeolite $\mathrm{Na}-\mathrm{A}$ on body weight gain and feed utilization of growing lambs fed urea or intact protein as a nitrogen supplement. Zeolites 4:127-132.

Prvulovic, D., S. Kosarcic, M. Popovic, D. Dimitrijevic, and L. G. Grubor. 2012. The influence of hydrated aluminosilicate on biochemical and haematological blood parameters, growth performance and carcass traits of pigs. J. Anim. Vet. Adv. $11: 134-140$.

Ramos, A. J. and E. Hernandez. 1996. In vitro aflatoxin adsorption by means of a montmorillonited silicate: A study of adsorption isotherms. Anim. Feed Sci. Technol. 62:263-269.

SAS Institute Inc. 1996. SAS user's guide: Statistics. Version 8 Ed. SAS Institute Inc., Cary, North Carolina.

Shurson, G. C., P. K. Ku, E. R. Miller, and M. T. Yokohama. 1984. Effects of zeolite A or clinoptilolite in diets of growing swine. J. Anim. Sci. 59:1536-1545.

Sibbald, I. R., S. J. Slinger, and G. C. Ashton. 1960. The weight gain and feed intake of chicks fed a ration diluted with cellulose or kaolin. J. Nutr. 72:441-446.

Tauqir, N. A. and H. Nawaz. 2001. Performance and economics of 
broiler chicks fed on rations supplemented with different levels of sodium bentonite. Int. J. Agric. Biol. 3:149-150.

Thiex, N. J., H. Manson, S. Anderson, and J. A. Persson. 2002. Determination of crude protein in animal feed, forage, grain, and oilseeds by using block digestion with copper catalyst and steam distillation into boric acid: Collaborative study. J. AOAC. Int. 85:309-317.

Venglovsky, J., Z. Pacajova, N. Sasakova, and M. Vucemilo. 1999. Adsorption properties of natural zeolite and bentonite in pig slurry from the microbiological point of view. Vet. Med. 44:339-344.

Vrzgula, L. and P. Bartko. 1984. Effects of clinoptilolite on weight gain and some physiological parameters of swine. In: Zeoagriculture. Use of natural zeolites in agriculture and aquaculture (Ed. W. G. Pond and F. A. Mumpton). Westview Press, Boulder Colorado. pp. 161-166.

Ward, T. L., K. L. Watkins, L. L. Southern, P. G. Hoyt, and D. D. French. 1991. Interactive effects of sodium zeolite-A and copper in growing swine: Growth, and bone and tissue mineral concentrations. J. Anim. Sci. 69:726-733.
Wiles, M. C., H. J. Huebner, G. E. Afriyie, R. J. Taylor, G. R. Bratton, and T. D. Phillips. 2004. Toxicological evaluation and metal bioavailability in pregnant rats following exposure to clay minerals in the diet. J. Toxicol. Environ. Health Part A. 67:863-874.

Wink, D. A., I. Hanbauer, F. Laval, J. A. Cook, M. C. Krishna, and J. B. Mitchell. 1994. Nitric oxide protects against the cytotoxic effects of reactive oxygen species. Ann. NY Acad. Sci. 738:265-278

Xia, M. S., C. H. Hu, and Z. R. Xu. 2005. Effects of copper bearing montmorillonite on the growth performance, intestinal microflora and morphology of weanling pigs. Anim. Feed Sci. Technol. 118:307-317.

Yannakopoulos, A., G. A. Terveni, F. A. Kassoli, A. Tsirambides, K Michailidis, A. Filippidis, and U. Lutat. 2000. Effects of dietary clinoptilolite-rich tuff on the performance of growingfinishing pigs. In: Natural zeolites for the third millennium (Ed. C. Coela and F. A. Mumpton). De Frede Editore, Napoli. pp. 471-481. 